\title{
Reply to Comment on "The timing and evolution of the post-glacial transgression across the Sea of Marmara shelf south of Istanbul" by Hiscott et al., Marine Geology 248, 228-236
}

\author{
K.K. Eriş ${ }^{a}{ }^{*}$, W.B.F. Ryan ${ }^{b}$, M.N. Çağatay ${ }^{a}$, G. Lericolais ${ }^{c}$, Ü. Sancar ${ }^{a}$, G. Menot ${ }^{d}$ and E. \\ Bard $^{\mathrm{d}}$
}

\footnotetext{
a Istanbul Technical University Faculty of Mines, Emcol, Geology Department Ayazağa, Istanbul Turkey

${ }^{\mathrm{b}}$ Lamont-Doherty Earth Observatory of Columbia University, Palisades, NY, USA

${ }^{c}$ Laboratoire de Environnements Sedimentaires, IFREMER, France

${ }^{d}$ Collège de France, CEREGE, UMR-6635, France
}

*: Corresponding author : K.K. Eriş, email address : keris@itu.edu.tr

\begin{abstract}
:
In their comment Hiscott and co-authors adhere rigidly to ages and sources for sedimentary units in the subsurface of the Marmara shelf that they have previously reported in their publications from 2002 through 2007. This adherence is in spite of a superior age-depth model from our $13 \mathrm{~m}$-long sediment core that penetrated deeply into the deposits under consideration and in disregard to the results of subsequent more-detailed and full-coverage mapping of the region under scrutiny. The age revisions are dismissed by the authors of the comment as representing sediments severely disturbed during coring. We rebut this criticism. The Bosporus source attributed by them to the sedimentary units sampled and dated by us appears to be driven by their conception that the Black Sea had a persistent outflow prior to its two-way connection with Marmara. Irrespective of whether the outflow was persistent, our reply shows that the drawing of the isopachs of the sedimentary units by Hiscott and co-authors was accomplished in a fashion to promote the Bosporus source hypothesis regardless of the geographic limits of their survey. The ages assigned to the units are equally indeterminate because the cores used by them have missing core tops of unknown lengths that are not discussed in their publications. Furthermore, the sub-bottom reflectors at the sites where the reflectors were calibrated to their only core without a missing top are actually hidden by the finite width of the bottom reflecting wavelet.
\end{abstract}

Keywords: Bosporus; Dardanelles; Marmara Sea; Black Sea; spillway 


\section{Introduction}

We address the following issues raised by Hiscott et al. (2008):

1) Their continuing assertion that the Unit 2 delta $(\Delta 2)$ of Hiscott et al. (2002) was sourced from the Bosporus (İstanbul) Strait and not from the nearby Kurbağalıdere River.

2) Their objection that the age calibration of 6.2 to 3.8 ka for the Unit 2 delta (Eriş et al., 2007) is too young when compared to the earlier calibration of 10 to 9 ka (Hiscott et al., 2002, 2007).

3) Their contention that the $-83 \mathrm{~m}$ sill depth in the Dardanelles (Çanakkale) Strait (Eriş et al., 2007 ) is too deep compared to their $-67 \pm 3 \mathrm{~m}$ elevation.

\section{Background}

Hiscott et al. (2002) proposed that a distinct lobe of prograding sediment reaching $20 \mathrm{~m}$ in thickness in the subsurface of the Marmara Sea shelf south of the Bosporus (İstanbul) Strait had been deposited as a sub-aqueous delta derived from sediments carried southward from the Strait by persistent Black Sea outflow between $\sim 10$ and 9 ka (all ages are years before 1950 and are without reservoir correction and without calibration to calendar years). The dating was deduced from radiocarbon measurements on samples from a single gravity core located at the distal edge of the lobe and by a procedure to tie the sediment lithology in this core to two key sub-bottom reflectors traced throughout a network of seismic reflection profiles. Hiscott et al. $(2007,2008)$ added substantiation to the early Holocene age with the addition of two nearby radiocarbon-dated piston cores.

The young stratigraphic level of climbing clinoforms in the post-glacial sediment cover of the Bosporus shelf valley had already been established by Ryan et al (1996) and is evident in Fig. 1. Oktay et al. (2002) referred to the sigmoidal-oblique pattern of the reflectors as indicative of transgressive depositional conditions. In pointing out that the subsurface deposit extends and thickens towards the east, they concluded that the Kurbağalıdere River had supplied the sediments.

In 2005 Gökaşan et al. describe an extremely-detailed mapping of the lobe using closely-spaced reflection profiles with more complete orthogonal coverage of the entire deposit than Hiscott et al. (2002). The delineation of the entire lobe by them and their measurements of the direction of the dip of the inclined foreset beds lent overwhelming support to the Kurbağalıdere River origin of the sediments comprising the clinoforms.

\section{Bullet 1 - Bosporus or Kurbağalıdere River source}

Hiscott et al. (2002) cite Oktay et al. (2002) but overlook any mention of the prior alternate hypothesis of river origin. Instead, Hiscott et al. (2002) independently develop a new reflector nomenclature and give the lobe a new name (Unit 2 delta, or D2). They write, "Unit 2 exhibits an oblique prograded seismic configuration where clinoforms terminate updip by toplap and erosional truncation at b1 and downdip by downlap onto b2." The top of the youngest clinoform is situated at a depth as shallow as $-40 \mathrm{~m}$.

Fig. 2 is a compilation of information extracted from Hiscott et al. (2002, 2007, 2008) and Gökaşan et al. (2005) to show the location of the Unit 2 delta lobe. We have created a new map 
because in Figs. 3A and 7A of Hiscott et al. (2002) neither the tracks of their profiles nor the contours showing the thickness of their Unit 2 were properly registered to the coordinates marked on the border of their maps. Since the coastline published in 2002 is of such a low-resolution as to provide no indication of the Kurbağalıdere River bay or the river itself, we took the coastline from the 2008 publication. We plotted the survey tracks directly from the shot point navigation. We co-registered the delta isopachs with respect to the ship tracks by superposition of the identical coastline in the aforementioned Figs. 3A and 7A. The core locations come from the tables in the 2002, 2007 and 2008 publications. However, we note that the coordinates of Core MAR02-111 contain a typographic error in both the 2007 band 2008 publications. The longitude must be $28^{\circ} 56.13^{\prime} \mathrm{E}$ instead of $28^{\circ} 36.13^{\prime} \mathrm{E}$ to conform to the location of this core in Fig. $5 \mathrm{~A}$ of Hiscott et al. (2007).

In our Fig. $2 \mathrm{~A}$ the bending of the isopachs to the north and northwest near the Kurbağalıdere River bay (the contour lines have been shaded gray by us in this region) appears to have been drawn by Hiscott et al. (2002) to imply a supply of material to the Unit 2 delta from the Bosporus Strait. However, as the reader can see, the extremities of the contour lines are not controlled by the survey data.

Fig. 2B illustrates the same region, but with the more closely-separated and spatially-complete coverage provided in Gökaşan et al. (2005). The shaded area encompasses the progradational part of their parasequence 2. The latter is equivalent to the clinoforms in the Unit 2 delta of Hiscott et al. (2002). The arrows represent the pathways of sediment supply as indicated from the dip directions of the foreset beds calculated at track intersections. The dip directions of Gökaşan et al. (2002) agree with those independently measured by Eriş et al. (2007) and reveal a radial pattern of sediment distribution emanating from the Kurbağalıdere Bay. The suggestion by Hiscott et al. (2008) that this pattern could have been generated instead by sediment discharged from the Bosporus is physically improbable since the coarse bedload on the floor of the Strait would have to have been lifted out of the Bosporus valley axis at $-60 \mathrm{~m}$ where the valley exits the Strait and then transported up the left (east) bank to reach the topset elevations that lie above $-40 \mathrm{~m}$. This diversion of Bosporus outflow to the delta upper surface as early as 10 ka ago when Marmara sealevel was no higher than $-50 \mathrm{~m}$ (Hiscott et al., 2007 - Fig. 4) could only have occurred if the Bosporus subaerial stream at that time was not confined to valley we see today in the subsurface (Gökaşan et al., 2005; Eriş et al., 2007) but lay to the east along the Asian shore where no such feature has been observed.

\section{Bullet 2 - Calibration of reflectors to cores}

Calibration of sediment layers in cores to the sub-bottom reflector surfaces that core barrels penetrate is often fraught with some ambiguity. First, the velocity of sound in the sediments must be known or estimated in order to determine the depth of a reflector, originally recorded in twoway travel time. For near-surface and water-saturated sediments the velocity of $1700 \mathrm{~m} / \mathrm{s}$ used by Hiscott et al. (2002) is a little higher than our experience from direct measurements $(1550 \mathrm{~m} / \mathrm{s})$, but the difference is insignificant in the following discussions.

The second issue is comparison of the depth in the subsurface of the seabed with distance below top of the recovered core. Traditional gravity coring in soft bottom sediment results in an incomplete recovery and an overall thickness less than the amount of core barrel penetration (Piggot, 1941, Leonard, 1990; Parker and Sills, 1990; Crusius and Anderson, 1991; Cumming et al., 1993). The proportion of recovery vs. penetration may depend upon the velocity of insertion, the diameter of the core cutter and its proportion to the thickness of the liner and core barrel, the presence of a restricting core-catcher and a restricting value through which water escapes, the resistive friction along the inner wall of the liner that is proportional to its surface area, cohesion of the sediment and the jetting away of the uppermost sediment by the hydrodynamics of the bowwave of the core barrel (Blomqvist, 1985, 1991). Core shortening (Lebel et al., 1982) is common 
with gravity coring devices. Strictly-speaking the substrate is not "compressed" as suggested by Crusius and Anderson (1991) because the sediment is water-saturated and water is incompressible. The substrate is instead "laterally thinned" (Wright, 1993) as it enters the core catcher.

Piston-coring devices overcome some of the problems of core shortening (Kullenberg, 1947), but create issues of their own. The particular issue raised in the comments of Hiscott et al. (2008) concerns over-recovery by suction from the piston. After the release from the trigger arm (Fig. 2), the status of the piston determines whether suction disturbs the sediment. For example, if the scope (amount of initially slacked piston wire exiting the core head and attached to the trigger arm assembly) is set too long, the bottom of the barrel with the piston in place arrives at the seabed before the piston wire is tensioned. In this case the barrel penetrates the seabed without retraction of the piston. As a result, sediment does not enter the barrel until the barrel has descended far enough for the slacked piston wire to finally come under tension. The distance traveled before tension is achieved amounts to the thickness of the seabed substrate that was bypassed and not sampled. This thickness is commonly called the "missing core top."

When the scope is set shorter than the recoil of the cable from the ship plus the length of freefall, the piston may experience an initial rapid acceleration from the de-tensioning of the ship wire. If the piston experiences the effects of de-tensioning before entry of the core catcher into the seabed only water is disturbed as it is sucked into the barrel ahead of the sediment. However, if the barrel has already made its entry into the seabed, sediment can be sucked in during the recoil. The practice for the Calypso coring device is to adjust the length of the scope to account for the desired freefall distance plus a little less than the calculated amount of recoil in order to recover some water ahead of the sediment. With an optimal adjustment, the cavity in the bottom of piston, when inspected after disassembly of the apparatus, is free of mud.

Measurements with accelerometers attached to both the Calypso coring device and the trigger arm assembly show that in water depths of $2000 \mathrm{~m}$, the recoil from the $17 \mathrm{~mm}$ diameter tensioned cable from the ship is $\sim 3$ to 4 meters (Bourillet et al., 2007). For the water depth of $-68 \mathrm{~m}$ for Core MD-2750 with a one-ton weight, the amount of recoil is $<0.5 \mathrm{~m}-$ a trivial value when setting the amount of scope. These accelerometer measurements also demonstrate that the $15 \mathrm{~m}$-long core barrel used for MD-2750 took less than $5 \mathrm{~s}$ in its fall from the trigger arm assembly to completion of penetration. The recoil from ship wire was completed within the first fraction of a second. Thus, the free fall height of $2.5 \mathrm{~m}$ that was set for Core MD-2750 would have been more than sufficient to account for the full recoil of the ship wire before entry of the barrel into the substrate.

Of paramount importance for complete and undisturbed cove recovery is an alert winch operator who pays out the ship wire slowly ( $<10 \mathrm{~m} /$ minute) as the device nears the seabed and then stops the winch immediately upon the slackening of the wire. A missing core top is commonly attributed to not stopping the winch quick enough and/or to scope that is too long in proportion to free fall and wire recoil.

The records kept in the core-repository in France indicate that the 15.5m-long barrel of Core MD2750 achieved a penetration of $13.5 \mathrm{~m}$, confirmed by the mud smeared on the outside of the core barrel. Furthermore, when the core was split, the visual bedding (as documented in the core photographs) was consistently horizontal and lacked the type of vertical flow deformation that would have been produced by sediment injected during an episode of over-recovery.

Like gravity coring devices, piston cores can also be of a length less than the amount of penetration that the barrel achieved in the substrate. For example, Hiscott et al. (2007) report under-recovery in piston core M02-45P extracted from a depth of $-69 \mathrm{~m}$ on the SW Black Sea shelf. By comparison of the upper layers in this core with those in gravity core M02-45TWC at the same location, they estimated that $1.1 \mathrm{~m}$ of the uppermost sediment from the seafloor was not present in the piston core. 
Cores MAR02-110 and MAR02-111 from Hiscott et al. (2007, 2008) were extracted from the Marmara Sea shelf south of Istanbul with the same Benthos piston-coring device and presumably the same scope settings as used in the Black Sea and may also have experienced underrecovery. To demonstrate this possibility, the radiocarbon ages for these cores and gravity core MAR98-09 from Hiscott et al. (2002) are plotted against distance below core top (Fig. 3). The resulting age-depth models affirm that up to 1.5 meters of uppermost seabed is most-likely missing in piston core MAR02-110. Piston core MAR02-111 appears also to be missing even more sediment as inferred both from its age-depth model (solid squares in Fig. 3) and because the reflection profile in Fig. 6 of Hiscott et al. (2007) shows a substantial amount of young Unit 1 sediments at this location which were not recovered in the core.

The age model for Core MAR98-09 (open circles in Fig. 3) is especially insightful in that there is apparently no missing top - exactly as one might expect for a gravity core lowered at a reasonable rate into the bottom. The radiocarbon dates (Hiscott et al., 2007) indicate an abrupt 8fold down-core change in sediment accumulation rate from slow $(5 \mathrm{~cm} / \mathrm{ka})$ above to faster (43 $\mathrm{cm} / \mathrm{ka}$ ) below. This change happens the same time in the past $(\sim 8.4 \mathrm{ka})$ as the 6 -fold increase in the age-depth model of Core MD-2750 (Eriş et al., 2007), located just $2.8 \mathrm{~km}$ away on the floor of the Bosporus shelf valley.

The similarity of the sedimentation rate changes at the same age in two cores that are located close to each other is suggestive of a response to the same sedimentary processes acting at that time. Both cores also show a down-core increase in grain size starting at the same level as the down-core increase in sedimentation rate. The change in Core MD-2750 occurs at the boundary between Units 3 and 4 of Eriş et al. (2007). These authors match this boundary to their reflector C. However, the change lithologic and sedimentation rate change in Core MAR98-09 occurs at 50 $\mathrm{cm}$ and is calibrated by Hiscott et al. (2002) to a different and more shallow reflector - namely the $\beta 1$ reflector as drawn in Fig. 10 in the Hiscott et al. (2002) publication which is equivalent to reflector A of Eriş et al. (2007).

Our Fig. 4 illustrates a segment of the Fig. 10 reflection profile in Hiscott et al. (2002) in order to demonstrate that the seafloor echo return (enclosed in oval A) comprises a persistent pattern of reverberations as the result of the seismic source signature that occupy more than $1.5 \mathrm{~ms}$ of twoway travel time (equivalent to $\sim 1 \mathrm{~m}$ of sub-bottom penetration when adjusted for a sound velocity of $1.55 \mathrm{~km} / \mathrm{s}$ in the sediment). The echo pattern observed at the seafloor is not unique and is repeated for deeper reflectors as shown in oval B in Fig. 4. This reverberation obscures the extrapolation of reflectors $\beta 1$ and $\beta 2$ to the location of Core MAR98-09, despite the presumption of Hiscott et al. (2002) that these reflectors are recognizable at the core site. Thus the assertion that reflector $\beta 1$ correlates to $50 \mathrm{~cm}$ in Core MAR98-09 and reflector $\beta 2$ intersects the recovered sediments at $110 \mathrm{~cm}$ does not meet the criteria of observation repeatable by others.

The consequence of the assignment of $\beta 1$ and $\beta 2$ to the top and bottom of the lower coarsegrained interval in core MAR98-09 is that this is the single tie point that imparted the 9 to $10 \mathrm{ka}$ age to the prograding clinoforms of the Unit 2 delta. We believe that an objective and experienced interpreter of Fig. 3 would not commit to such a rigid interpretation considering both the obscuring nature of the seafloor reverberation and the real possibly that this gravity core is shortened like most gravity cores in respect to the magnitude of penetration (Lebel et al., 1982; Blomqvist, 1985, 1991).

The calibration of the Core MD-2750 age-model of Eriş et al. (2007) to reflectors $\beta 1$ and $\beta 2$ does not have such uncertainty. The sub-bottom reflectors at this site lie well below any bottom echo reverberation. Furthermore, the age-model does not indicate a missing core top. Thus the younger mid-Holocene age of the Unit 2 delta established by Core MD-2750 seems to be on firmer ground than the age obtained from gravity cores with unknown core-shortening, piston cores with missing tops and calibration sites where the bottom-echo reverberation obscures shallow sub-bottom reflecting interfaces. 
The match of sedimentation rates and grain-size trends in cores MAR98-09 and MD-2750, both with identical chronology, is a testament that both cores intersected the $\beta 1$ and $\beta 2$ reflectors and both cores sampled sediments of age equivalent to the time of the formation of the Unit 2 delta lobe. On which core should one rely most for the reflector calibration in order to date the Unit 2 delta? In our opinion the younger mid-Holocene 3.8 to $6.2 \mathrm{ka}$ age of Unit 2 delta established by the $13 \mathrm{~m}$-long Core MD-2750 seems to be on firmer ground than the 9 to $10 \mathrm{ka}$ age obtained from a short gravity cores taken at a site where the bottom-echo reverberation obscures shallow subbottom reflecting interfaces.

\section{Bullet 3 - Sill depth in the Dardanelles Strait}

The reader might ask, "What does the depth of the Dardanelles (Çanakkale) Strait have to due with a disagreement about the age of a delta south of Istanbul at the other end of the Marmara Sea." The answer actually concerns another delta, called the mid-shelf delta $1(\Delta 1)$ that corresponds to Unit 5 in Hiscott et al. (2002). Delta 1 lies within the axis of the Bosporus shelf valley (Fig. 1). Hiscott et al. (2002) initially interpreted this feature as built from sediment supplied by an earlier Black Sea outflow through the Bosporus Strait between 29.5 and $23.5 \mathrm{ka}$ bp, although they had accomplished no direct sampling of the sediments. They arrived at this age assignment using the elevation of the top of the deposit and an interval of time within Marine Isotopic Stage 3 when global sea level had reached above this elevation from its preceding stage 4 lowstand.

In their subsequent 2007 publication Hiscott et al. abandon the MIS 3 age assignment in deference to a younger $\sim 16$ to $14.7 \mathrm{ka}$ post-glacial interval corresponding to the episode of rapid shrinkage of the Eurasian Ice sheet and meltwater delivery to Marmara via the Black Sea. At this time, the global ocean lay below the Dardanelles spillway, and Marmara was still a brackish to semi-fresh lake with a surface pinned to its outlet. The depth of the youngest strata of delta 1 set a constraint for the outlet. The sill in the spillway to the Aegean had to be higher than the top of the deposit in order for Unit 5 sediments to have accumulated in a submerged environment. This line of reasoning is based entirely on the arbitrary age given to Unit 5 by Hiscott et al. (2007) that once again was obtained by circular reasoning and not supported by any direct sampling. Apparently an inferred age can trump not only an actual 11.5-10.5 ka age obtained by sampling (Eriş et al., 2007) but also measurements of the sill using reflection profiling. No wonder that Hiscott et al. (2007) are adamant in dismissing the deeper $-83 \mathrm{~m}$ value in Eriş et al. (2007) because it is the main defense for their $\sim 16$ to 14.7 age allegation for the Unit 5 delta 1.

Several independent research teams have established that the incursion of Mediterranean water into the Marmara Sea occurred at 12 ka (Çağatay et al., 2000; Tolun et al., 2002; Sperling et al., 2003; Beck et al., 2007). Prior to this and at intermittent times of Black Sea lake outflow, the surface of the downstream Marmara lake was locked to its Dardanelles outlet. One finds a continuous paleo-shoreline close to the edge of the northern Marmara shelf that deviates from $85 \mathrm{~m}$ along its entire length by less than $\pm 4 \mathrm{~m}$ (Çağatay et al., 2003; Polonia et al., 2004: Cormier et al., 2006; Eriş, 2007). Thus there should be no surprise that the depth of the shoreline coincides with the outlet (a subsequent inlet) depth used by Eriş et al. (2007). Coarse beach deposits belonging to this shoreline have been sampled and are covered by mud containing marine shells with an $11.5 \pm 0.5 \mathrm{ka}$ age (Polonia et al., 2004), as one would logically expect.

When the Marmara Sea was discharging its lake water though its outlet, the Dardanelles served as the location of the spillway. The cascade eroded a subaerial valley deep into Paleozoic bedrock (Fig 6). The mapping of subsurface of the modern Strait with reflection profiles (Ryan et al, 2006; Yaltırak et al., 2000, 2002) has located a sill in the bare rock at an elevation of $-85 \mathrm{~m}$. Contrary to the assertions of Hiscott et al. (2008), none of the discussion above or in the publication of Eriş et al. (2007) rule out episodes of pre-12 ka evaporative drawdown of the Marmara lake below its outlet (Aksu et al., 2002). In fact the -108 m depth of the bedrock incision 
of the Bosporus shelf valley shown in Fig. 1 is supportive of the drawdown hypothesis. The floor of this once empty valley continues to $-125 \mathrm{~m}$ near the shelf break.

\section{Summary}

Comments to published articles and the replies to the comments can often result in arguments that remain unresolved because of different observations, viewpoints and interpretations. In the present case both research teams have mapped with similar tools the same deposits and agree with the identification of the same reflectors. Our reply simply points out that the strata under examination have been directly sampled and dated by Eriş et al. (2007) at locations and at subbottom levels not obscured by seafloor reverberation. In the challenge to the age assignments of the reflectors, Hiscott et al. (2008) have implied that Core MD-2750 is so messed up that the 13 meters of recovered sediment only correspond to a core barrel penetration of 4.5 meters. Let the reader decide between the information derived from the thoroughly documented Core MD-2750 and the information in the publications of Hiscott et al. where one can not find any comment at all upon the likely realities of missing tops and shortening in their own cores.

\section{References}

Aksu, A.E., Hiscott, R.N., Yaşar, D., Işler, F.I., Marsh, S., 2002. Seismic stratigraphy of Late Quaternary deposits from the south-western Black Sea shelf: evidence for non-catastrophic variations in sea-level during the last $<10,000$ years. Mar. Geol. 190, 61-94.

Beck, C., Mercier de Lepinay, B., Schneider, J.L., Cremer, M., Çağatay, M.N., Wendenbaum, E., Boutareaud, S., Menot, G., Schmidt, S., Weber, O., Eris, K., Armijo, R., Meyer, B., Pondard, N., Gutscher, M.A., and the MARMACORE Cruise Party, Turon, J.L., Labeyrie, L., Cortijo, E., Gallet, Y., Bouquerel, H., Görür, N., Gervais, A., Castera, M.H., Londeix, L., Resseguier, A. and Jaouen, A., 2007. Late Quaternary co-seismic sedimentation in the Sea of Marmara's deep basins, Sedimentary Geology, 199, 65-89.

Blomqvist, S., 1985. Reliability of core sampling of soft bottom sediment-an in situ study. Sedimentology 32, 605-6 12.

Blomqvist, S., 1991. Quantitative sampling of soft-bottom sediments: Problems and solutions. Mar. Ecol. Prog. Ser. 72, 295-304.

Bourillet, J.-F., Damy, G., Migeon, S., Sultan, N., Dussud, L., 2007. Behaviour of a piston corer from accelerometers and new insights on associated disturbances. 6th International Conference on Offshore Site Investigation and Geotechnics, Confronting New Challenges and Sharing Knowledge, London (UK), 57-62.

Çağatay, N., Görür, N., Algan, O., Eastoe, C.J., Tchapalyga, A., Ongan, D., Kuhn, T., Kuscu, I., 2000. Late Glacial-Holocene paleoceanography of the Marmara Sea: timing of connections with the Mediterranean and the Black Seas. Mar. Geol. 167, 191-206.

Çağatay, M.N. Görür, N. Polonia, A., Demirbağ, E., Sakınç, M.. Cormier, M.-H., Capotondi, L.. McHugh, C Emre, Ö., Eriş, K. (2003). Sea level changes and depositional environments in the İmit Gulf, eastern Marmara Sea, during the late glacial-Holocene period. Marine Geology, 202, 159-173.

Cormier, M.-H., Seeber, L., McHugh, C.M.G., Polonia, A., Çağatay, M.N., Emre, Ö., Gasperini, L., Görür, N., Bertoluzzi, G., Bonatti, E., Ryan, W.B.F., Newman, K.R., 2006. The North Anatolian 
fault in the Gulf of Izmit (Turkey): rapid vertical motion in response to minor bends of a nonvertical continental transform. J. Geophys. Res. 111, B04102. doi:10.1029/2005JB003633.

Crusius, J., Anderson, R.F. 1991. Core compression and surficial sediment loss of lake sediments of high porosity caused by gravity coring. Limnol. Oceanogr. 36, 1021-1031.

Cumming, B. F., Glew, J.R., Smol, J.P., Davis, R.B. and Norton, S.A., 1993. Comment on "Core compression and surficial sediment loss of lake sediments of high porosity caused by gravity coring" (Crusius and Anderson). Limnol. Oceanogr. 38, 695-699.

Eriş, K.K., Ryan, W.B.F., Çağatay, M.N., Sancar, U., Lericolais, G., Ménot, G., Bard, E., 2007. The timing and evolution of the post- glacial transgression across the Sea of Marmara shelf south of İstanbul. Mar. Geol. 243, 57-76.

Eriş, K.K., 2007. Marmara Denizi'nde Orta Pleyistosen'den günümüze deniz seviyesi değişimleri. (Middle Pleistocene to recent sealevel changes in the Sea of Marmara), PhD thesis (September, 2007), 208 p. İstanbul Technical University, Eurasia Institute of Earth Sciences, İstanbul.

Gökaşan, E., Algan, O., Tur, H., Meriç, E., Türker, A., Şimşek, M., 2005. Delta formation at the southern entrance of Istanbul Strait (Marmara Sea, Turkey): a new interpretation based on high resolution seismic stratigraphy. Geo-Mar. Lett. 25, 370-377.

Hiscott, R.N., Aksu, A.E., Yaşar, D., Kaminski, M.A., Mudie, P.J., Kostylev, V., MacDonald, J., Işler, F.I., Lord, A.R., 2002. Deltas south of the Bosphorus Strait record persistent Black Sea outflow to the Marmara Sea since $10 \mathrm{ka}$. Mar. Geol. 190, 95-118.

Hiscott, R.N., Aksu, A.E., Mudie, P.J., Kaminski, M.A., Abrajano, T., Yaşar, D., Rochon, A., 2007. The Marmara Sea Gateway since 16 ka: non-catastrophic causes of paleoceanographic events in the Black Sea at $8.4 \mathrm{ka}$ and $7.15 \mathrm{ka}$. In: Yanko-Hombach, V., Gilbert, A.S., Panin, N., Dolukhanov, P. (Eds.), The Black Sea Flood Question: Changes in Coastline, Climate, and Human Settlement. Springer, Dordrecht, The Netherlands, pp. 89-117.

Hiscott, R.N., Aksu, A.E., Mudie, P.J., 2008. Comment on "The timing and evolution of the postglacial transgression across the Sea of Marmara shelf south of İstanbul" by Eriş et al., Marine Geology 243, 57-76. Mar. Geol. 248, 228-236.

Kullenberg, B., 1947. The piston core sampler. Svenska hydrog.-biol. Komm. Sr. Tredge Seien Hydrografi, Bd. 1, 1-46.

Lebel, J., Silverberg, N., Sundby, B., 1982. Gravity core shortening and pore water chemical gradients. Deep-Sea Res. 29, 1365-I 372.

Leonard, E., 1990. An assessment of sediment loss and distortion at the top of short gravity cores. Sediment. Geol. 66, 57-63.

Oktay, F.Y., Gökaşan, E., Sakınç, M., Yaltırak, C., İmren, C., Demirbağ, E., 2002. The effects of the North Anatolian Fault Zone on the latest connection between Black Sea and Sea of Marmara. Mar. Geol. 190, 367-382.

Parker, W. R., Sills, G.C., 1990. Observation of corer penetration and sample entry during gravity coring. Mar. Geophys. Res. 12, 101-107.

Piggot, C. S., 1941. Factors involved in submarine core sampling. Geol. Soc. Am. Bull. 52, 15131524. 
Polonia A., Gasperini L. , Amorosi A. , Bonatti E., Çağatay, N., Capotondi L., Cormier M.-H., Görür N., McHugh C., Seeber L., 2004. Holocene Slip Rate of the North Anatolian Fault beneath the Sea of Marmara. In press Earth and Planet. Sci. Letters, 227: 411-426.

Ryan, W.B.F., W.C. Pitman, W.C. III, Major, C.O., Shimkus, K., Moskalenko, K.V., Jones, G.A., Dimitrov, P., Görür, N., Sakinç, M., Yüce, H., 1996. An abrupt drowning of the Black Sea shelf at 7.5 k yr BP. Geo-Eco-Marina 2, 115-126.

Sperling, M., Schmiedl, G., Hemleben, Ch., Emeis, K.C., Erlenkeuser, H., Grootes, P.M., 2003. Black Sea impact on the formation of eastern Mediterranean sapropel S1? Evidence from the Marmara Sea. Palaeogeogr. Palaeoclim. Palaeoecol. 190, 9-21.

Tolun, L., Çağatay, M.N., Carrigan, W.J., 2002. Organic geochemistry and origin of Late GlacialHolocene sapropelic layers and asociated sediments in Marmara Sea. Mar. Geol. 190, 47-60.

Wright, H. E., 1993. Core compression. Limnol. Oceanogr. 38(3), 699-701.

Yaltırak, C., Alpar, B.,Sakınç, M.,Yüce,H., 2000. Origin of the Strait of Çanakkale (Dardanelles): regional tectonics and the Mediterranean Marmara incursion. Mar. Geol., 164,139-156.

Yaltırak, C. Sakınç, M., Aksu, A. E., Hiscott, R. N. Galleb, B. and Ulgen, U.B., 2002. Late Pleistocene uplift history along the southwestern Marmara Sea determined from raised coastal deposits and global sea-level variations, Mar. Geol., 190, 283-305.

\section{Figures}

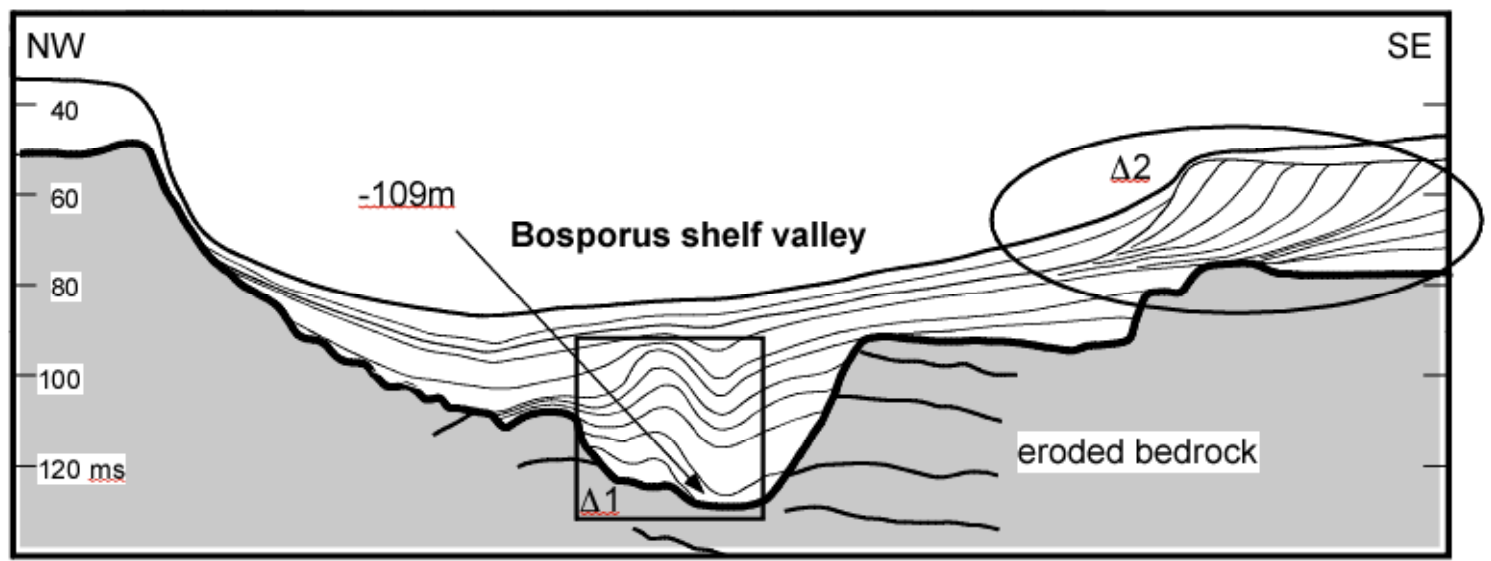

Fig. 1. Reflection profile interpretation from Ryan et al. (1996) showing the prograding deposit with climbing clinoforms (oval). These deposits belong to the Unit 2 delta mapped by Hiscott et al. (2002). Note that the top and base of this deposit occur at a relatively high and young level within in the post-glacial sediments that cover the late-glacial lowstand erosion surface (bold line). The preceding deposit (box) called the Unit 5 delta 1 by Hiscott et al. (2002) is confined to the Bosporus shelf valley- a location that is more likely to have been in the pathway of sedimentladen water exiting the Bosporus spillway from the upstream Black Sea lake. 


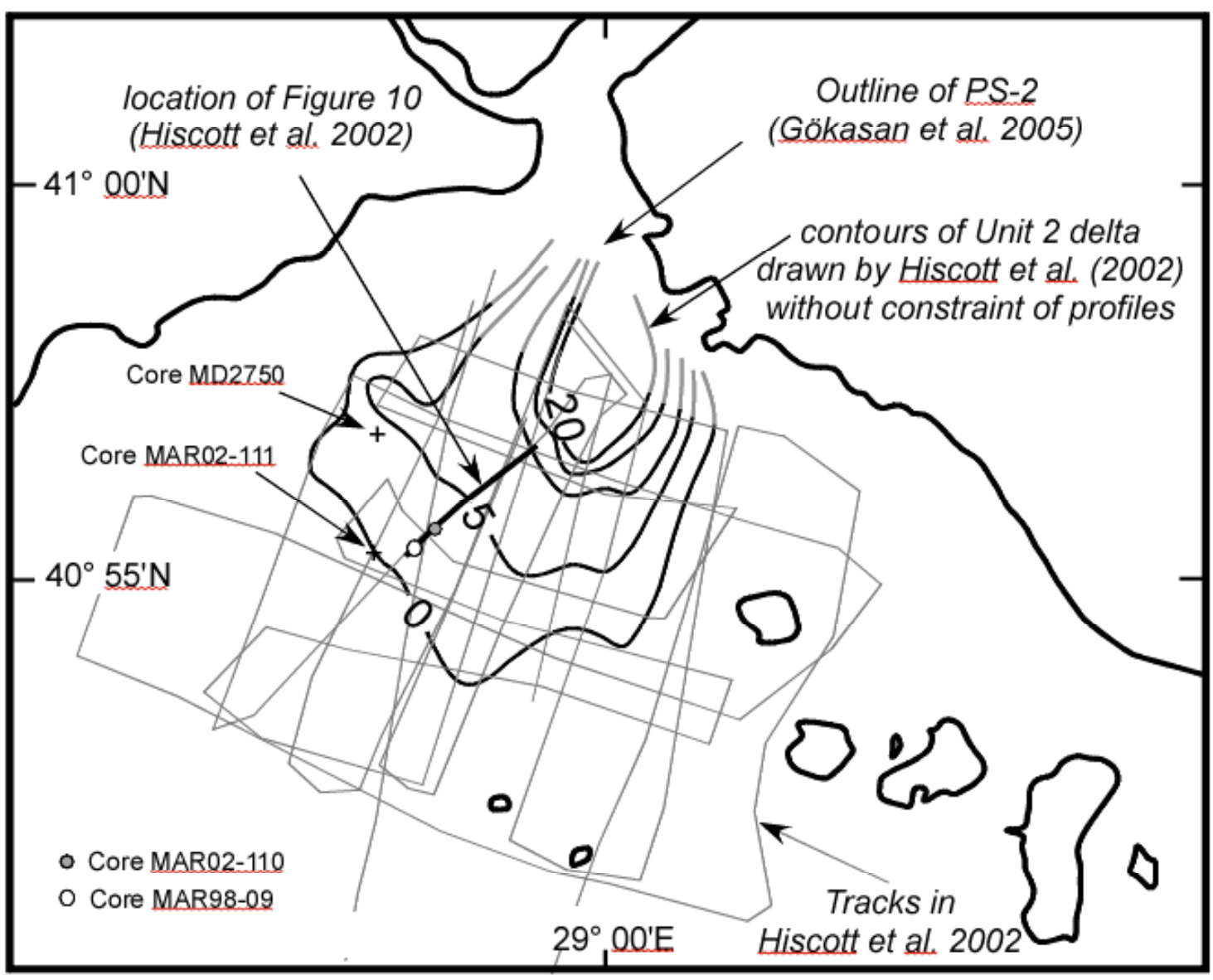

Fig. 2A. Survey tracks on the Marmara shelf south of the Bosporus Strait. Note that the bending of the contours (shaded gray) for the sediment thickness of the Unit 2 delta was drafted that way in order to imply a southern-directed supply of sediment from the Bosporus Strait. However, the contour lines of the northern part of the deposits are not constrained by data. 


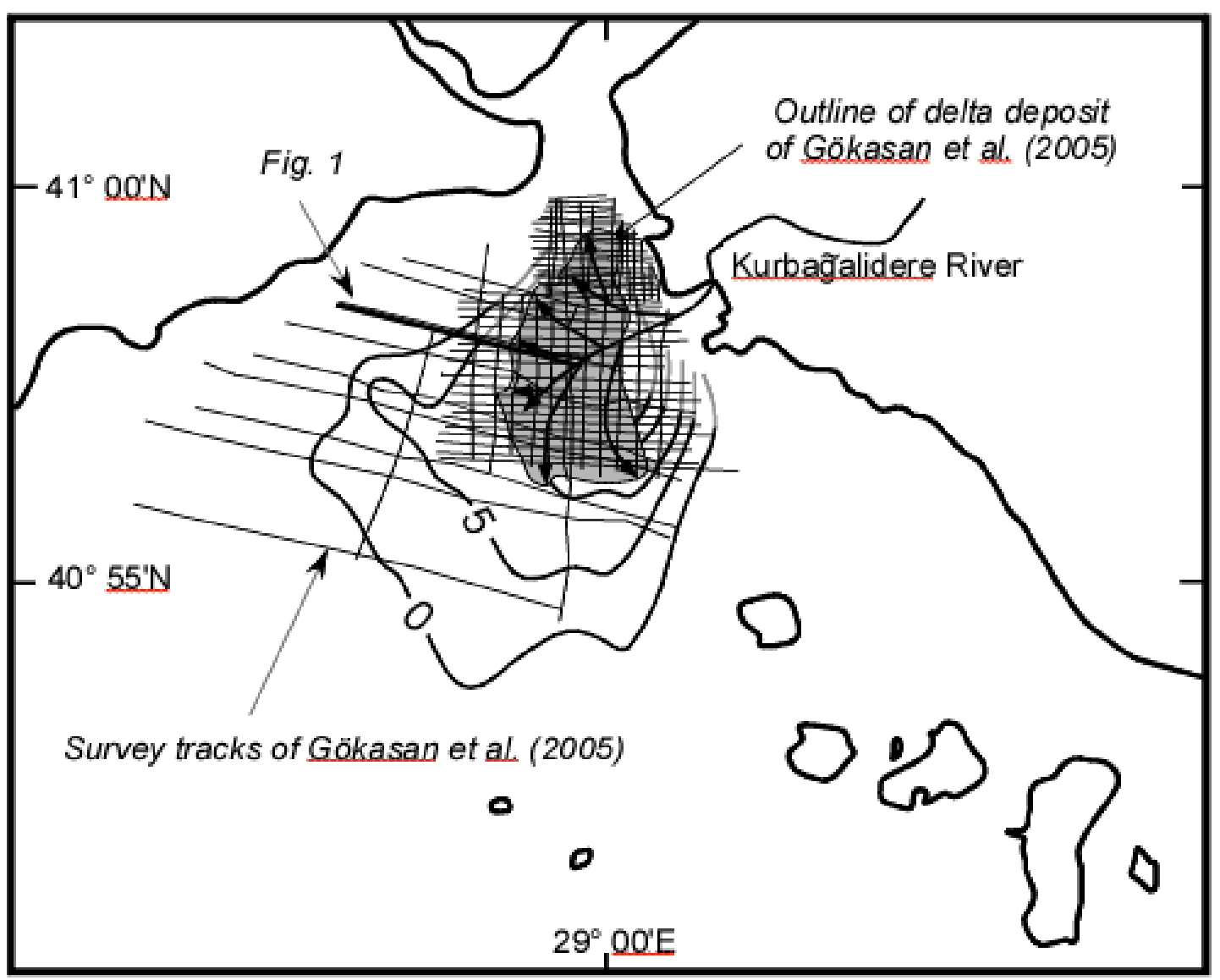

Fig. 2B. The dense and broader survey coverage (Gökaşan et al., 2005) which shows that the Unit 2 delta is sourced from the Kurbağalıdere River. The arrow tip directions of the inferred sediment transport are based on the actual measured dips of foreset deposits. The isopachs in meters from Hiscott et al. (2002) are displayed for comparison to Fig. 2A. The stippled region encompasses the radial prograding clinoforms of the sediment body. The thick track line indicates the location of the reflection profile interpreted in Fig. 1. 


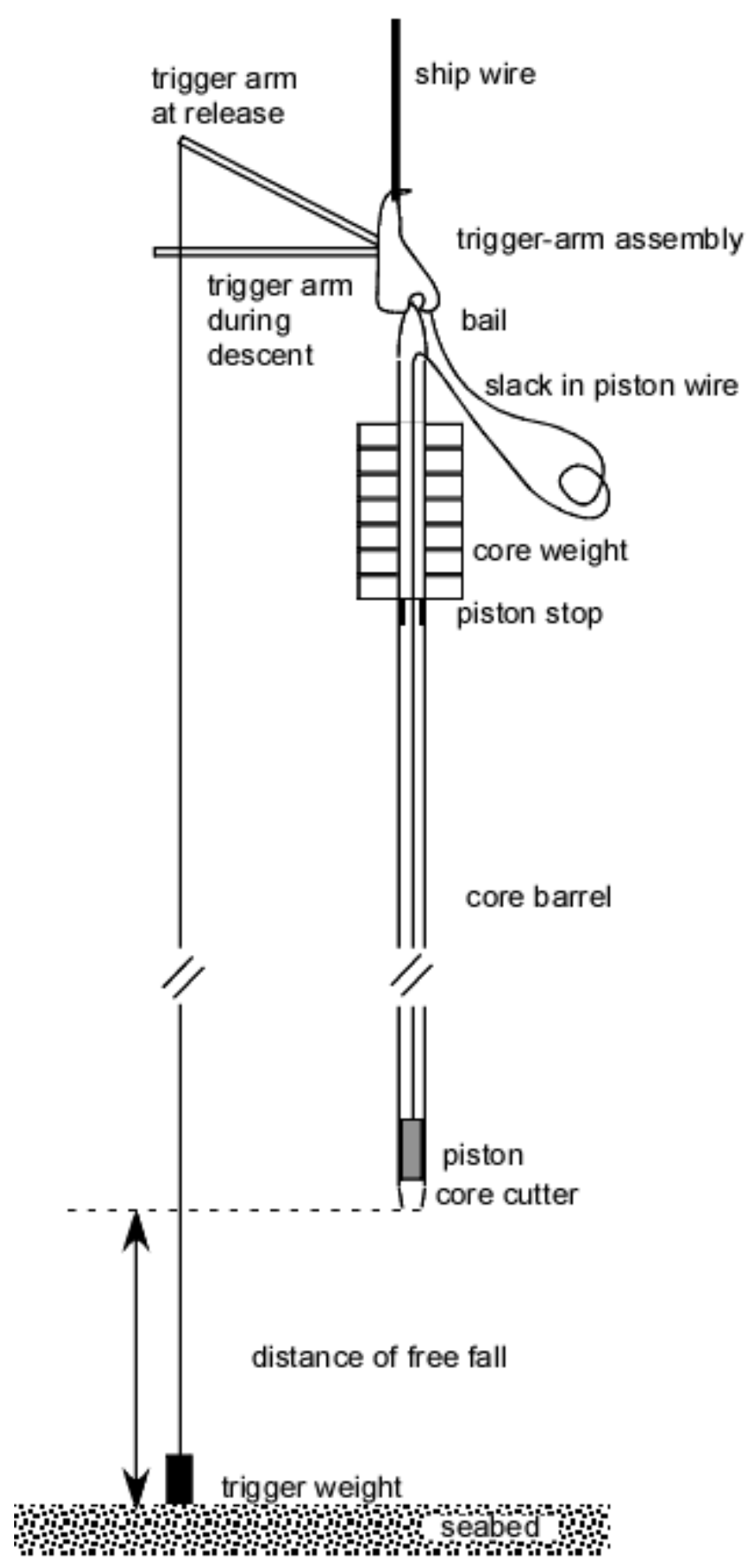

Fig. 3. Schematic diagram of the Calypso piston-coring device (after Bourillet et al., 2007). Various terms are cited in the text. "Scope" is the length of the slack in the piston wire. The scope length is set to start the initial upward travel of the piston just before the core catcher enters the bottom. Thus the recoil of tensioned ship wire occurs ahead of any recovery of the substrate. The optimum length of the scope assures the capture of some water above the core top. Lack of mud on the piston confirms that there is little to no missing core top. 


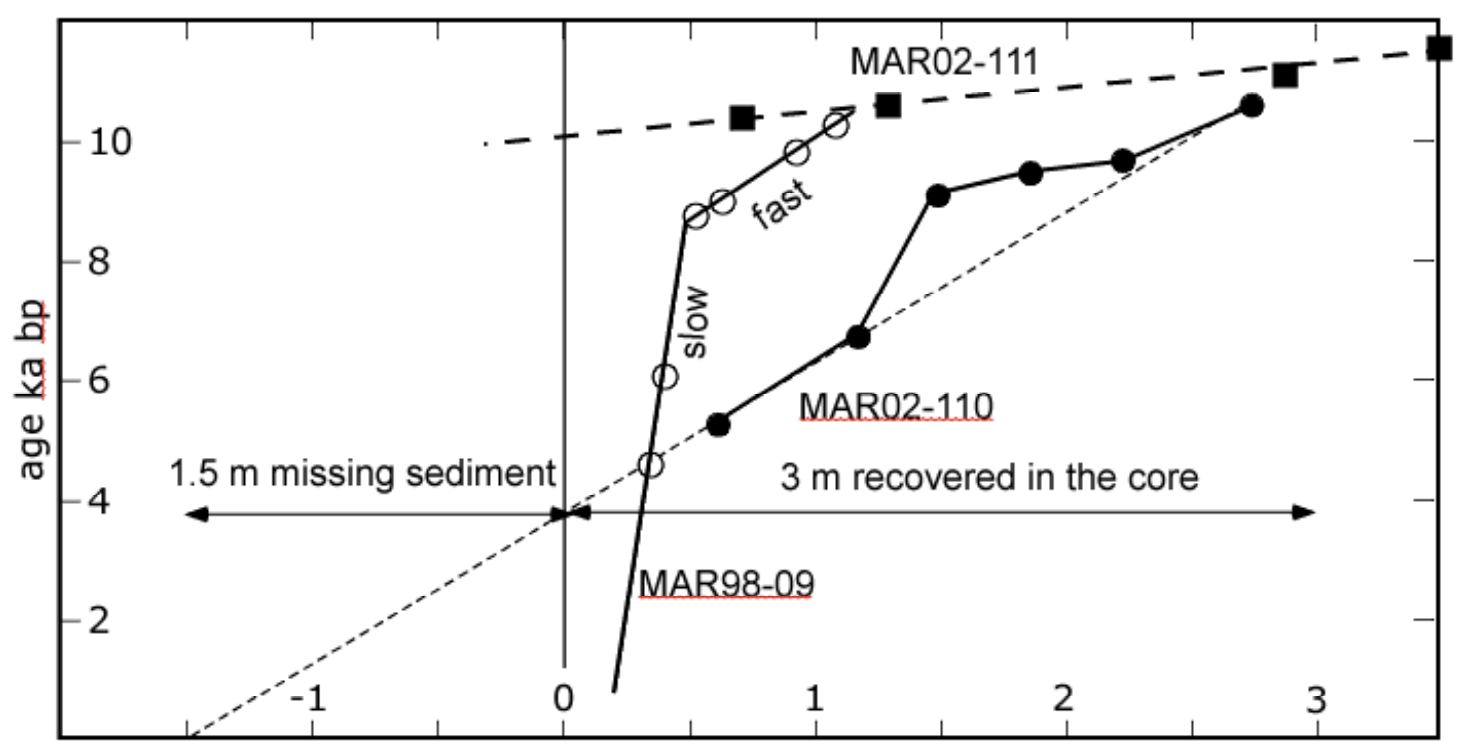

meters below recovered core top

Fig. 4. Age depth models for three cores discussed in the text. Two cores (MAR02-110 and MAR02-111) have old sediment near their tops that suggests young seabed material bypassed and not sampled during the piston coring operation. The calibration of reflectors to particular levels in such cores must take into account the amount of missing sediment before the distance below core top can be used as a reference for distance below the seafloor. 

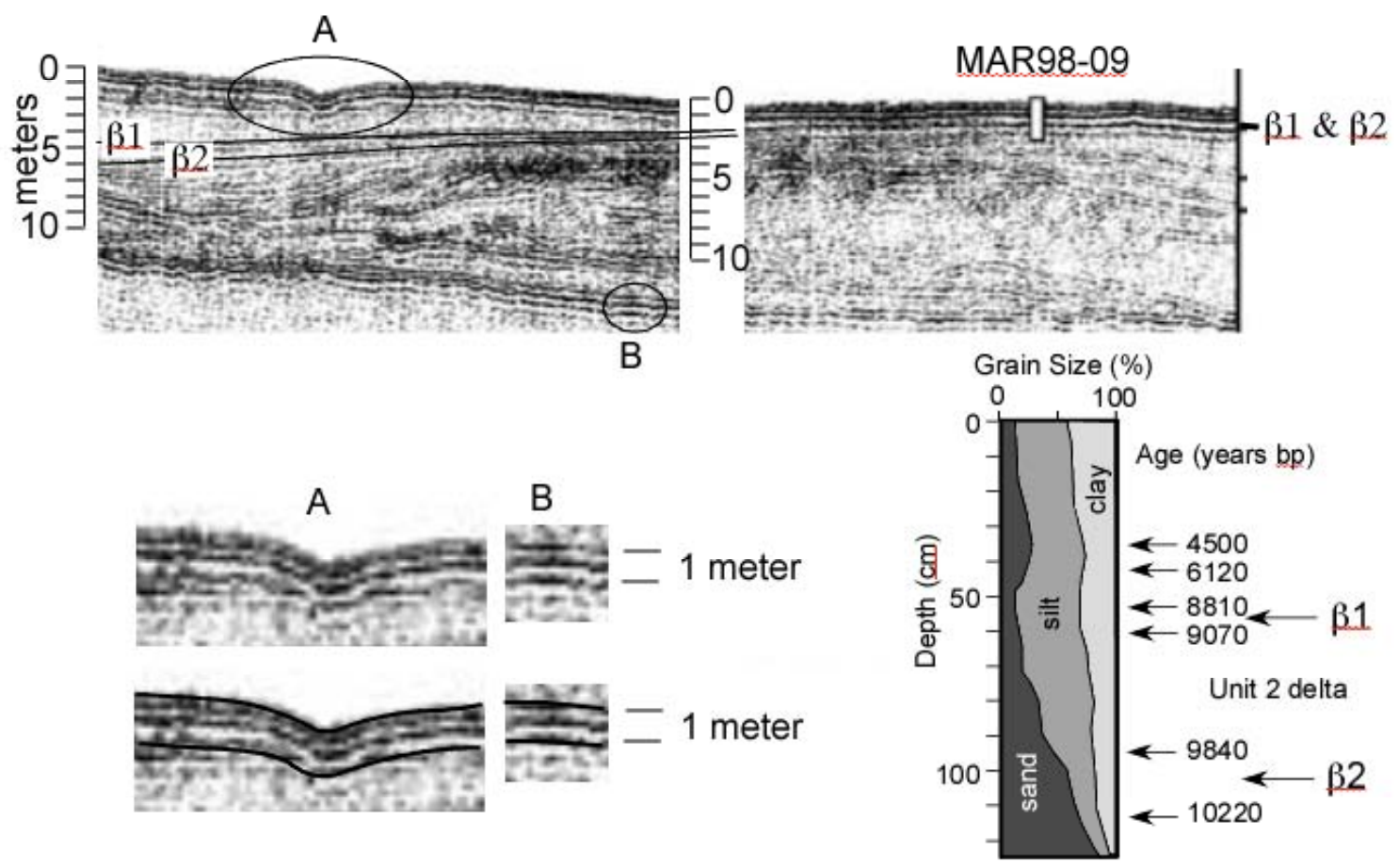

Fig. 5. Reflection profile from Fig. 10 in Hiscott et al. (2002). The two sides of the profile have been adjusted depth-wise for the change in altitude of the towfish during the gap. Reflectors $\beta 1$ and $\beta 2$ shoal to the right but are obscured at the location of core MAR98-09 by the seabed echo reverberation. Two examples of the echo returns are shown in the ovals and enlarged below. The identical patterns for the seabed return $(A)$ and the deeper horizon (B) indicate that the echo triplet produced by the seismic source obscures the internal structure of the upper 1.5 meters of the substrate. The percentages of sand, silt and clay in core MAR98-09 are reproduced from Hiscott et al. (2002, Fig. 12) along with the radiocarbon dates, the assignments of reflectors $\beta 1$ and $\beta 2$ and their placement of Unit 2. However, the reflectors are masked at the core site by the bottom echo reverberation and reflector placement is arbitrary. Were reflectors $\beta 1$ and $\beta 2$ to have been placed instead at 30 and $45 \mathrm{~cm}$ in the core, then the pulse in percent sand in that interval would correspond to Unit 2 and one would find no disagreement with the reflector correlations reported by Eriş et al. (2007). In that case the deeper sandy unit would belong to Hiscott et al. (2002) Unit 5. 


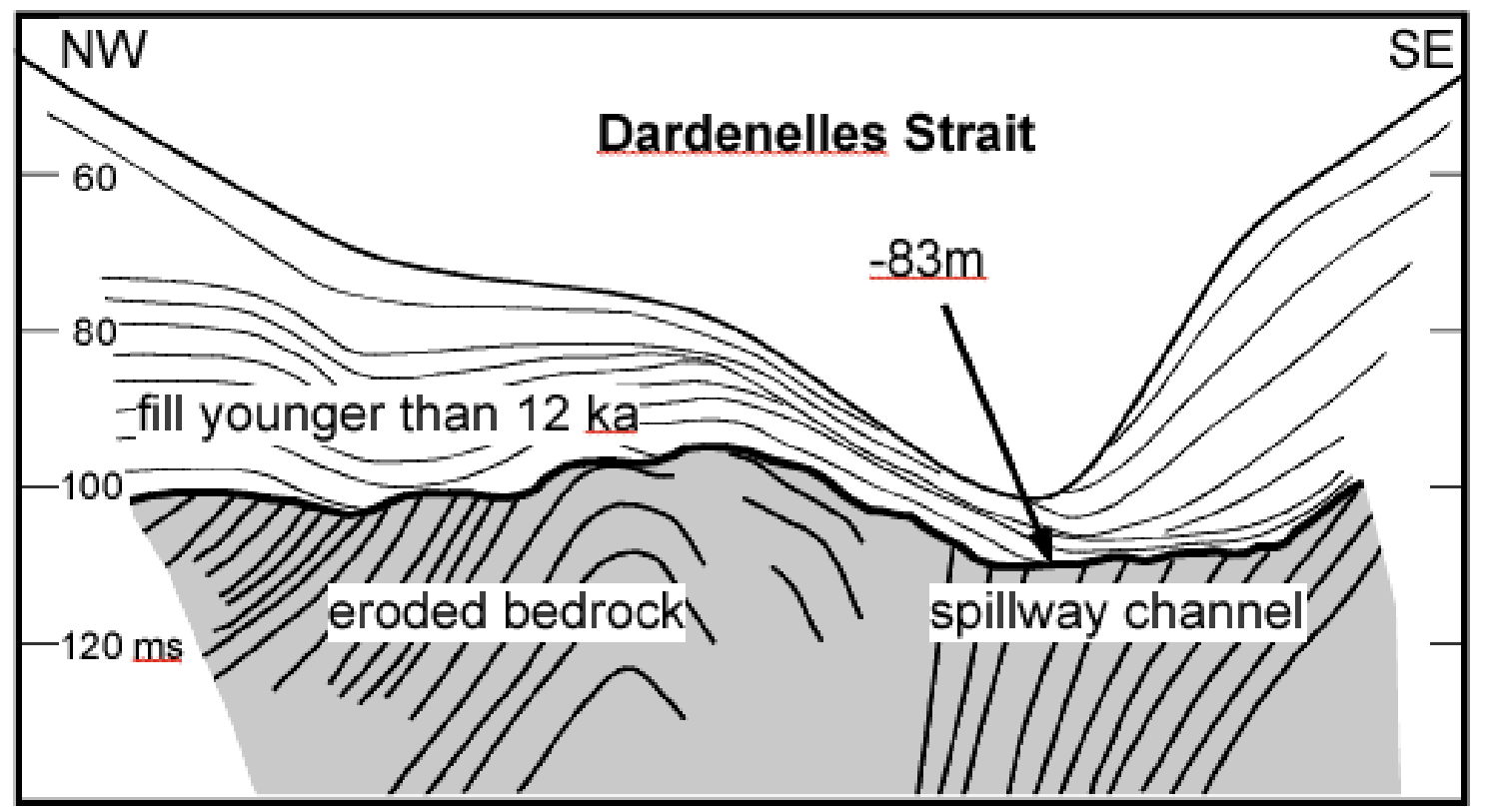

Fig. 6. Reflection profile interpretation from Ryan et al. (1996) of a reflection profile across the modern Dardanelles Strait. Prior to $12 \mathrm{ka}$, the Strait was the location of a subaerial valley containing a spillway from Marmara cut into Paleozoic bedrock and stripped away the previous soil. After reconnection of the Aegean Sea with Marmara, the valley floor began to drown and has progressively filled with marine sediment. 